\title{
An Electrochemical Ethylamine/Acetonitrile Redox Method for Ambient Hydrogen Storage
}

\author{
Authors: Dezhen $\mathrm{Wu}^{1} \uparrow$, Jialu $\mathrm{Li}^{1} \uparrow$, Libo $\mathrm{Yao}^{1}$, Rongxuan $\mathrm{Xie}^{1}$, and Zhenmeng Peng ${ }^{1 *}$
}

\section{Affiliations:}

${ }^{1}$ Department of Chemical, Biomolecular, and Corrosion Engineering, The University of Akron; Akron, $\mathrm{OH}, 44325$, United States.

*Corresponding author. Email: zpeng@uakron.edu

Abstract: Hydrogen storage presents a major difficulty in the development of hydrogen economy. Herein, we report a new electrochemical ethylamine/acetonitrile redox method for hydrogen storage with an 8.9 wt.\% theoretical storage capacity under ambient conditions. This method exhibits low onset overpotentials of $0.19 \mathrm{~V}$ in $\mathrm{CH}_{3} \mathrm{CH}_{2} \mathrm{NH}_{2}$ dehydrogenation to $\mathrm{CH}_{3} \mathrm{CN}$ and $0.09 \mathrm{~V}$ in $\mathrm{CH}_{3} \mathrm{CN}$ hydrogenation to $\mathrm{CH}_{3} \mathrm{CH}_{2} \mathrm{NH}_{2}$ using commercial Pt black catalyst. By assembling a full cell that couples $\mathrm{CH}_{3} \mathrm{CH}_{2} \mathrm{NH}_{2} / \mathrm{CH}_{3} \mathrm{CN}$ redox reactions with hydrogen evolution and oxidation reactions, we demonstrate a complete hydrogen storage cycle at fast rates, with only $52.5 \mathrm{~kJ} / \mathrm{mol}$ energy consumption for $\mathrm{H}_{2}$ uptake and release at a rate of $1 \mathrm{~L} / \mathrm{m}^{2} \cdot \mathrm{h}$. This method provides a viable hydrogen storage strategy that meets the 2025 Department of Energy onboard hydrogen storage target.

20 One-Sentence Summary: A new electrochemical ethylamine/acetonitrile redox method is reported to achieve efficient, high-capacity hydrogen storage with fast uptake and release rate and low energy consumption under ambient conditions. 
Main Text: Hydrogen is an appealing energy carrier that can potentially replace conventional fossil fuels in the development of a clean, sustainable hydrogen economy, which would resolve environmental problems caused by the combustion of the non-renewable resources while also meeting the rising demand for energy $(1,2)$. However, hydrogen storage has remained a major roadblock in the hydrogen economy development. Currently, hydrogen is mainly stored in the form of either compressed gas or cryogenic liquid. These methods are ill-suited for commercial applications due to their insufficient energy storage density (3). To make matters worse, extreme storage conditions are required, which not only result in a significant increment of the cost but also raise safety concerns (3). As a matter of fact, the state-of-the-art methods fall short of the 2025 Department of Energy (DOE) onboard hydrogen storage target of $5.5 \mathrm{wt} . \%$ under $85{ }^{\circ} \mathrm{C}$ and 12 bar.

To overcome these challenges, there have been extensive research efforts to discover alternative hydrogen storage methods in the past few decades. The developed methods can be primarily classified into two categories, i.e., physisorption and chemical conversion, depending on the storage mechanisms. The physisorption methods use large-surface, light-weight storage materials, which can weakly adsorb hydrogen molecules to their surface via the Van der Waals attraction force (3). Although many promising materials have been carefully investigated, such as carbon nanotubes $(4,5)$, zeolites $(6,7)$, metal organic frameworks (MOFs) $(8,9)$, and covalent organic frameworks (COFs) (10), only a relatively low storage capacity (typically less than 1 2 wt.\%) can be obtained, even under their best preformed low temperature and high pressure conditions (11). The chemical conversion methods involve uptake of hydrogen by storage materials via hydrogenation and release of hydrogen via decomposition. A range of chemical compounds, for instance, aluminum and magnesium hydrides $(12,13)$, metal complex hydrides (14), and amides/imides (15), have been considered as promising candidates and extensively studied. Many of these chemical compounds possess $>5.5 \mathrm{wt} . \%$ theoretical hydrogen uptake/release that exceeds the DOE goal of storage capacity. However, to date, none of them have been able to meet the DOE goals regarding operation conditions and cost. This is because these chemical hydrogen storage processes generally go through complex reaction pathways with a high energy barrier. Furthermore, either the hydrogen uptake or release reaction would be endothermic from a thermodynamics point of view. Extremely high temperature and pressure conditions were thus required to complete a hydrogen storage cycle in these previous studies (3).

In this work, we report a new, electrochemical ethylamine/acetonitrile redox method for efficient, high-capacity hydrogen storage under completely ambient conditions. The amine/nitrile redox couple is selected due to their moderate chemical polarity and relatively simple hydrogenation and dehydrogenation pathways, which would aid reaction activation and reduce the energy barrier. Electrochemical potential provides the driving force in $\mathrm{CH}_{3} \mathrm{CH}_{2} \mathrm{NH}_{2}$ dehydrogenation under ambient conditions, rather than high temperature and pressure that are typically required to thermally drive an endothermic process. We demonstrate an effective, complete cycle of $\mathrm{CH}_{3} \mathrm{CN}$ hydrogenation to $\mathrm{CH}_{3} \mathrm{CH}_{2} \mathrm{NH}_{2}$ for hydrogen uptake and $\mathrm{CH}_{3} \mathrm{CH}_{2} \mathrm{NH}_{2}$ dehydrogenation to $\mathrm{CH}_{3} \mathrm{CN}$ for hydrogen release at low overpotentials, using commercial $\mathrm{Pt}$ black catalyst in an electrochemical cell. The studied $\mathrm{CH}_{3} \mathrm{CH}_{2} \mathrm{NH}_{2} / \mathrm{CH}_{3} \mathrm{CN}$ system has a theoretical $\mathrm{H}_{2}$ storage capacity of $8.9 \mathrm{wt} . \%$, well surpassing the $5.5 \mathrm{wt} . \%$ DOE target. This study offers a new, effective hydrogen storage strategy that can be extended to many other amine/nitrile redox systems and would help advance the hydrogen economy development. 
The electrochemical conversion between $\mathrm{CH}_{3} \mathrm{CH}_{2} \mathrm{NH}_{2}$ and $\mathrm{CH}_{3} \mathrm{CN}$ in an alkaline aqueous electrolyte occurs via a four-electron transfer dehydrogenation/hydrogenation process and exhibits a standard redox potential of $0.13 \mathrm{~V}$ vs. RHE (Fig. 1a). The reaction properties were studied by conducting electrochemical measurements under half-cell test condition, with the working electrode loaded with commercial Pt black catalyst for promoting the kinetics. Fig. 1b and $\mathrm{S} 1$ show cyclic voltammetry (CV) and linear sweep voltammetry (LSV) data collected in different electrolytes. In an $1 \mathrm{M} \mathrm{CH}_{3} \mathrm{CH}_{2} \mathrm{NH}_{2}+1 \mathrm{M} \mathrm{NaOH}$ electrolyte, the $\mathrm{CV}$ curve exhibited cathodic currents below $0 \mathrm{~V}$, which corresponded to hydrogen evolution reaction (HER), and anodic currents above $0.32 \mathrm{~V}$, which was attributed to $\mathrm{CH}_{3} \mathrm{CH}_{2} \mathrm{NH}_{2}$ electrochemical oxidation because the anodic currents became negligible with the absence of $\mathrm{CH}_{3} \mathrm{CH}_{2} \mathrm{NH}_{2}$ in the electrolyte. Proton nuclear magnetic resonance $\left({ }^{1} \mathrm{H}\right.$ NMR) spectroscopy characterizations of the reacted solution found $\mathrm{CH}_{3} \mathrm{CN}$ to be the only liquid product (Fig. 1c), confirming effective, selective $\mathrm{CH}_{3} \mathrm{CH}_{2} \mathrm{NH}_{2}$ dehydrogenation to $\mathrm{CH}_{3} \mathrm{CN}$. The measured low onset overpotential of about $0.19 \mathrm{~V}$ suggested a fast dehydrogenation kinetics. This could benefit from a moderate polarity and basicity of amine molecules, which would allow for efficient activation towards electrochemical oxidation $(16,17)$. The occurrence of $\mathrm{CH}_{3} \mathrm{CH}_{2} \mathrm{NH}_{2}$ dehydrogenation on the working electrode was accompanied by HER on the counter electrode, as evidenced by mass spectrometry (MS) detection of $\mathrm{H}_{2}$ product in the gas phase (Fig. 1d).

With the addition of $\mathrm{CH}_{3} \mathrm{CN}$ to the electrolyte, the $\mathrm{CV}$ curve showed more significant cathodic currents below $0 \mathrm{~V}$ vs. RHE. Moreover, there was a slight positive shift in the onset potential to $0.04 \mathrm{~V}$. These results suggested the occurrence of $\mathrm{CH}_{3} \mathrm{CN}$ electrochemistry with an onset overpotential of $0.09 \mathrm{~V}$, besides HER. ${ }^{1} \mathrm{H}$ NMR spectrum of the reaction product showed $\mathrm{CH}_{3} \mathrm{CH}_{2} \mathrm{NH}_{2}$ as a major product and minor fractions of $\left(\mathrm{CH}_{3} \mathrm{CH}_{2}\right)_{2} \mathrm{NH}$ and $\left(\mathrm{CH}_{3} \mathrm{CH}_{2}\right)_{3} \mathrm{~N}$ side products (Fig. 1e) $(18,19)$. This confirmed $\mathrm{CH}_{3} \mathrm{CN}$ can be effectively converted to $\mathrm{CH}_{3} \mathrm{CH}_{2} \mathrm{NH}_{2}$ via electrochemical hydrogenation. It is worth noting that the $\mathrm{CH}_{3} \mathrm{CN}$ hydrogenation efficiency and selectivity can be further improved by catalyst research. For instance, Zhang et al. reported a complete prevention of amine dimers and trimers formation and suppression of $\mathrm{HER}$ in $\mathrm{CH}_{3} \mathrm{CN}$ hydrogenation to $\mathrm{CH}_{3} \mathrm{CH}_{2} \mathrm{NH}_{2}$ using a $\mathrm{Cu}$ catalyst (19). Xia et al. investigated several catalyst materials in $\mathrm{CH}_{3} \mathrm{CN}$ hydrogenation and found composition effects on the reaction activity and selectivity properties (18).

The effects of electrolyte $\mathrm{pH}$ and concentration on both $\mathrm{CH}_{3} \mathrm{CH}_{2} \mathrm{NH}_{2}$ dehydrogenation and $\mathrm{CH}_{3} \mathrm{CN}$ hydrogenation reaction properties were investigated. The highest current density for $\mathrm{CH}_{3} \mathrm{CH}_{2} \mathrm{NH}_{2}$ dehydrogenation was obtained with $0.5 \mathrm{M} \mathrm{NaOH}$, suggesting the optimal $\mathrm{pH}$ for this reaction (Fig. S2 and S3). With an increase in the $\mathrm{CH}_{3} \mathrm{CH}_{2} \mathrm{NH}_{2}$ concentration, there was an improvement in the dehydrogenation rate together with a suppression in HER (Fig. S4 - S6). This can be explained by strong adsorption of amino groups to Pt catalyst $(16,17)$, with which a higher concentration of $\mathrm{CH}_{3} \mathrm{CH}_{2} \mathrm{NH}_{2}$ would lead to more active sites being occupied for its dehydrogenation and less active sites for HER. Chronoamperometry experiments at $0.5 \mathrm{~V}$ vs. RHE show time dependency of the current density (Fig. S7), which had a drastic decrease at the beginning and became more stabilized thereafter. The negligible influence of electrode rotation rate on the $\mathrm{CH}_{3} \mathrm{CH}_{2} \mathrm{NH}_{2}$ dehydrogenation indicated minimal mass transfer limitation for this reaction under the studied condition (Fig. S8). For the reverse $\mathrm{CH}_{3} \mathrm{CN}$ hydrogenation reaction, a higher current density was obtained with an increase in the $\mathrm{pH}$ and a decrease in $\mathrm{CH}_{3} \mathrm{CN}$ concentration (Fig. S9 and S10). Because $\mathrm{CH}_{3} \mathrm{CN}$ hydrogenation and HER occur simultaneously in the same potential region, there would be an interplay between the two processes that led to the observed changes. While the electrode rotation rate did not show a significant effect on the current density in $\mathrm{CH}_{3} \mathrm{CN}$ hydrogenation region, it considerably affected the current density in 
the positive potential range that corresponded to hydrogen oxidation reaction (HOR), particularly when the electrolyte was saturated with $\mathrm{H}_{2}$ (Fig. S11). This was consistent with previous HOR studies and was attributed to a mass transfer limitation in this reaction (20).

The temperature effect on the two half-cell reactions were studied by measuring the LSV change with temperature, which was used for evaluating the reaction activity property (Fig. S12 and S13). Fig. If shows the obtained Arrhenius plot, which determined an apparent activation energy (E $\mathrm{E}_{\mathrm{a}}$ ) value of $52.4 \mathrm{~kJ} / \mathrm{mol}$ at $0.5 \mathrm{~V}$ vs. RHE for $\mathrm{CH}_{3} \mathrm{CH}_{2} \mathrm{NH}_{2}$ dehydrogenation and $11.6 \mathrm{~kJ} / \mathrm{mol}$ at $-0.05 \mathrm{~V}$ vs. RHE. Although the latter accounted for $\mathrm{CH}_{3} \mathrm{CN}$ hydrogenation with a mix of HER, these low $\mathrm{E}_{\mathrm{a}}$ values revealed the rapid reaction kinetics and agreed well with the observed low overpotentials in $\mathrm{CH}_{3} \mathrm{CH}_{2} \mathrm{NH}_{2}$ dehydrogenation and $\mathrm{CH}_{3} \mathrm{CN}$ hydrogenation. Benefiting from their low activation energy, a minimal increase in the potential difference between the two halfcell reactions is needed to drastically improve the reaction current density (Fig. 1g), implying feasibility of utilizing these two reactions to realize energy-efficient, complete cycle of hydrogen storage.

Figure 2a illustrated the blueprint for a sustainable hydrogen economy, in which the electrochemical $\mathrm{CH}_{3} \mathrm{CH}_{2} \mathrm{NH}_{2} / \mathrm{CH}_{3} \mathrm{CN}$ redox method plays a crucial role for hydrogen storage that bridges hydrogen production and various applications. The great potential of this new method was demonstrated by assembling a custom-made $10 \mathrm{~cm}^{2}$ electrochemical cell and investigating the overall hydrogenation/dehydrogenation process to simulate a complete $\mathrm{H}_{2}$ uptake/release cycle (Fig. S14). In $\mathrm{H}_{2}$ uptake experiments, $\mathrm{CH}_{3} \mathrm{CN}$ and $\mathrm{H}_{2}$ were fed to the cathode and anode, at which $\mathrm{CH}_{3} \mathrm{CN}$ hydrogenation and HOR occurred with an applied cell voltage (Fig. S15). Fig. 2b shows chronoamperometry tests of the cell at different voltages and the corresponding $\mathrm{H}_{2}$ uptake performances. A notable current was measured even with a low cell voltage of $0.1 \mathrm{~V}$. Except for the initial drop due to the capacitive current effect, the cell maintained a consistent current of roughly $6 \mathrm{~mA}$ throughout the experiment, indicating good durability for $\mathrm{CH}_{3} \mathrm{CN}$ hydrogenation and $\mathrm{HOR}$ reactions. An increase in the cell voltage led to enhancements in the $\mathrm{H}_{2}$ uptake rate. This was evidenced by the measured current and the $\mathrm{CH}_{3} \mathrm{CH}_{2} \mathrm{NH}_{2}$ generation rate quantified with $\mathrm{NMR}$ analysis (Fig. S16), with $\mathrm{CH}_{3} \mathrm{CH}_{2} \mathrm{NH}_{2}$ being produced at as high as $93.1 \mathrm{mmol} / \mathrm{m}^{2} \cdot \mathrm{h}$ rate at $0.3 \mathrm{~V}$. With increasing cell voltage, the faradaic efficiency for $\mathrm{CH}_{3} \mathrm{CH}_{2} \mathrm{NH}_{2}$ production gradually increased, reaching about $60 \%$ at $0.3 \mathrm{~V}$. The non-superior $\mathrm{CH}_{3} \mathrm{CH}_{2} \mathrm{NH}_{2}$ faradaic efficiency was caused by side reactions including HER and generation of $\left(\mathrm{CH}_{3} \mathrm{CH}_{2}\right)_{2} \mathrm{NH}$ and $\left(\mathrm{CH}_{3} \mathrm{CH}_{2}\right)_{3} \mathrm{~N}$ minor products, which was in agreement with the results under half-cell condition and can be improved by applying a more suitable catalyst $(18$, 19). For $\mathrm{H}_{2}$ release, $\mathrm{CH}_{3} \mathrm{CH}_{2} \mathrm{NH}_{2}$ was fed to the anode and dehydrogenated to $\mathrm{CH}_{3} \mathrm{CN}$ with an applied cell voltage (Fig. S17). This was coupled with HER at the cathode, transforming the hydrogen stored in $\mathrm{CH}_{3} \mathrm{CH}_{2} \mathrm{NH}_{2}$ molecules to $\mathrm{H}_{2}$ gas. Fig. 2c shows $\mathrm{CV}$ and chronoamperometry results of the cell, with $\mathrm{H}_{2}$ generation being continuously measured using on-line mass spectroscopy (MS) (Fig. S18-S19). The $\mathrm{H}_{2}$ generation became significant once the cell voltage turned positive, with the generation rate increasing rapidly with the voltage and the faradaic efficiency determined to be close to $100 \%$. This was consistent with the finding of $\mathrm{CH}_{3} \mathrm{CN}$ as the only liquid product and $\mathrm{H}_{2}$ as the only gas product, confirming an excellent selectivity in $\mathrm{H}_{2}$ release via $\mathrm{CH}_{3} \mathrm{CH}_{2} \mathrm{NH}_{2}$ dehydrogenation. The cell durability was evaluated by conducting chronoamperometry experiments at different voltages. The current showed a rapid drop in the first few minutes and then became steadier throughout the remaining experiment with a constant voltage being applied (Fig. S20), suggesting promising cell durability. The current decayed more rapidly when the voltage was periodically turned on and off for simulating cell startup and shutdown operations (Fig. 2c), and the decay became more substantial as the voltage increased 
(Fig. S21 and S22). This was likely due to a gradual deactivation of the Pt black catalyst under these stability test conditions. Regardless of the cell voltage, the faradaic efficiency was consistently greater than $94 \%$ and exhibited no signs of decrease.

We conducted an energy consumption analysis using the cell LSV data to assess the technical feasibility of this new electrochemical $\mathrm{CH}_{3} \mathrm{CH}_{2} \mathrm{NH}_{2} / \mathrm{CH}_{3} \mathrm{CN}$ redox method for hydrogen storage application. Fig. 3a shows the measured cell I-V plots during $\mathrm{H}_{2}$ uptake and release processes as well as the calculated power consumption in the individual steps, based on which the total energy consumption to complete a hydrogen storage cycle at any designated hydrogen uptake and release rate was computed (Fig. 3b). It appeared that the energy consumption per mole of $\mathrm{H}_{2}$ for a complete storage cycle was a function of $\mathrm{H}_{2}$ uptake and release rate, with extremely low energy consumption at slow rates. For instance, the $\mathrm{H}_{2}$ uptake and release at a rate of $1 \mathrm{~L} / \mathrm{m}^{2} \cdot \mathrm{h}$ required only $52.5 \mathrm{~kJ} / \mathrm{mol}$ energy consumption, which was dramatically smaller compared to $286 \mathrm{~kJ} / \mathrm{mol}$ energy generation when the stored $\mathrm{H}_{2}$ is combusted for application, suggesting the energyefficient nature of the electrochemical $\mathrm{CH}_{3} \mathrm{CH}_{2} \mathrm{NH}_{2} / \mathrm{CH}_{3} \mathrm{CN}$ redox method. Additionally, the hydrogen uptake/release temperature and pressure conditions should also be taken into account for cost and safety concerns. Although certain metal hydrides can achieve a high storage capacity, for instance, $7 \mathrm{wt} . \%$ for $\mathrm{MgH}_{2}$ and $10 \mathrm{wt} . \%$ for $\mathrm{AlH}_{3}(21-25)$, their hydrogen uptake/release process requires either $>300{ }^{\circ} \mathrm{C}$ temperature or $>20$ bar pressure, if not both (Fig. $3 \mathrm{c})$. A very recent study by Liu et al. reported a new multi-layered $\mathrm{Ti}_{2} \mathrm{CT}_{\mathrm{x}}$ material with 8.8 wt.\% storage capacity at 60 bar, but achieving only 4 wt.\% under ambient conditions (26). It is unprecedented that the electrochemical $\mathrm{CH}_{3} \mathrm{CH}_{2} \mathrm{NH}_{2} / \mathrm{CH}_{3} \mathrm{CN}$ redox method is capable of completing a hydrogen uptake and release cycle with 8.9 wt.\% storage capacity under entirely ambient conditions. To the best of our knowledge, this new method is the only approach that meets the 2025 DOE onboard hydrogen storage target in terms of storage capacity $(\geq 5.5 \mathrm{wt} . \%)$, max delivery temperature $\left(\leq 85^{\circ} \mathrm{C}\right)$, and max delivery pressure $(\leq 12$ bar $)$.

\section{Conclusion}

In summary, a novel electrochemical $\mathrm{CH}_{3} \mathrm{CH}_{2} \mathrm{NH}_{2} / \mathrm{CH}_{3} \mathrm{CN}$ redox method was studied for ambient $\mathrm{H}_{2}$ storage, which utilized electrochemical conversion between the two chemicals. The $\mathrm{CH}_{3} \mathrm{CH}_{2} \mathrm{NH}_{2}$ dehydrogenation to $\mathrm{CH}_{3} \mathrm{CN}$ using a commercial Pt black catalyst exhibited a low onset overpotential of $0.19 \mathrm{~V}$, a moderate activation energy of $52.4 \mathrm{~kJ} / \mathrm{mol}$ at $0.5 \mathrm{~V} \mathrm{vs}$. RHE, and produced $\mathrm{CH}_{3} \mathrm{CN}$ as the only product, indicating fast reaction kinetics and excellent selectivity. The rapid $\mathrm{CH}_{3} \mathrm{CN}$ hydrogenation to $\mathrm{CH}_{3} \mathrm{CH}_{2} \mathrm{NH}_{2}$ was also evidenced by a low onset overpotential of $0.09 \mathrm{~V}$ and a low activation energy of $11.6 \mathrm{~kJ} / \mathrm{mol}$ at $-50 \mathrm{mV}$ vs. RHE. A complete hydrogen uptake and release cycle was demonstrated with full cell testing, with 93.14 $\mathrm{mmol} / \mathrm{m}^{2} \cdot \mathrm{h} \mathrm{CH} \mathrm{CH}_{2} \mathrm{NH}_{2}$ generation rate and $60 \%$ faradaic efficiency for $\mathrm{H}_{2}$ uptake at $0.3 \mathrm{~V}$ cell voltage, and $0.34 \mathrm{~mol} / \mathrm{m}^{2} \cdot \mathrm{h} \mathrm{H}$ generation rate and $>94 \%$ faradaic efficiency for $\mathrm{H}_{2}$ release at 0.4 $\mathrm{V}$ cell voltage. It is worth mentioning these results were obtained in a simply assembled electrochemical cell using commercial Pt black catalyst, implying the $\mathrm{H}_{2}$ uptake and release rate as well as the faradaic efficiency can be further improved with cell engineering and new catalyst research. With $8.9 \mathrm{wt} . \%$ theoretical $\mathrm{H}_{2}$ storage capacity, ambient reaction conditions, and 52.5 $\mathrm{kJ} / \mathrm{mol}$ low energy consumption for $\mathrm{H}_{2}$ uptake and release at a rate of $1 \mathrm{~L} / \mathrm{m}^{2} \cdot \mathrm{h}$, this study demonstrated the $\mathrm{CH}_{3} \mathrm{CH}_{2} \mathrm{NH}_{2} / \mathrm{CH}_{3} \mathrm{CN}$ redox method as a viable hydrogen storage strategy that would contribute to advancing the hydrogen economy development.

\section{References and Notes}


Today. 57, 39-44 (2004).

2. S. S. Penner, Steps toward the hydrogen economy. Energy. 31, 33-43 (2006).

3. P. Jena, Materials for hydrogen storage: Past, present, and future. J. Phys. Chem. Lett. 2, 206-211 (2011).

4. Dillon, A., Jones, K., Bekkedahl, T. et al. Storage of hydrogen in single-walled carbon nanotubes. Nature 386, 377-379 (1997).

5. P. Chen, $\mathrm{X}$. Wu, J. Lin, K. L. Tan, High $\mathrm{H}_{2}$ uptake by alkali-doped carbon nanotubes under ambient pressure and moderate temperatures. Science. 285, 91-93 (1999).

6. J. Weitkamp, M. Fritz, S. Ernst, in Proceedings from the ninth international zeolite conference (Elsevier, 1993), pp. 11-19.

7. J. Dong, X. Wang, H. Xu, Q. Zhao, J. Li, Hydrogen storage in several microporous zeolites. Int. J. Hydrogen Energy. 32, 4998-5004 (2007).

8. S. S. Kaye, A. Dailly, O. M. Yaghi, J. R. Long, Impact of preparation and handling on the hydrogen storage properties of $\mathrm{Zn}_{4} \mathrm{O}$ (1, 4-benzenedicarboxylate) 3 (MOF-5). J. Am. Chem. Soc. 129, 14176-14177 (2007).

9. J. Yang, A. Grzech, F. M. Mulder, T. J. Dingemans, Methyl modified MOF-5: a water stable hydrogen storage material. Chem. Commun. 47, 5244-5246 (2011).

10. Z. Ke, Y. Cheng, S. Yang, F. Li, L. Ding, Modification of COF-108 via impregnation/functionalization and Li-doping for hydrogen storage at ambient temperature. Int. J. Hydrogen Energy. 42, 11461-11468 (2017).

11. S. Niaz, T. Manzoor, A. H. Pandith, Hydrogen storage: Materials, methods and perspectives. Renew. Sustain. Energy Rev. 50, 457-469 (2015).

12. C. M. Jensen, K. J. Gross, Development of catalytically enhanced sodium aluminum hydride as a hydrogen-storage material. Appl. Phys. A. 72, 213-219 (2001).

13. P. de Rango, P. Marty, D. Fruchart, Hydrogen storage systems based on magnesium hydride: from laboratory tests to fuel cell integration. Appl. Phys. A. 122, 1-20 (2016).

14. M. B. Ley, L. H. Jepsen, Y.-S. Lee, Y. W. Cho, J. M. B. Von Colbe, M. Dornheim, M. Rokni, J. O. Jensen, M. Sloth, Y. Filinchuk, Complex hydrides for hydrogen storage-new perspectives. Mater. Today. 17, 122-128 (2014).

15. W. I. F. David, M. O. Jones, D. H. Gregory, C. M. Jewell, S. R. Johnson, A. Walton, P. P. Edwards, A mechanism for non-stoichiometry in the lithium amide/lithium imide hydrogen storage reaction. J. Am. Chem. Soc. 129, 1594-1601 (2007).

16. A. Adenier, M. M. Chehimi, I. Gallardo, J. Pinson, N. Vilà, Electrochemical oxidation of aliphatic amines and their attachment to carbon and metal surfaces. Langmuir. 20, 82438253 (2004).

17. J. Ghilane, P. Martin, H. Randriamahazaka, J. C. Lacroix, Electrochemical oxidation of primary amine in ionic liquid media: Formation of organic layer attached to electrode surface. Electrochem. commun. 12, 246-249 (2010).

18. R. Xia, D. Tian, S. Kattel, B. Hasa, H. Shin, X. Ma, J. G. Chen, F. Jiao, Electrochemical reduction of acetonitrile to ethylamine. Nat. Commun. 12, 1-8 (2021). 
19. D. Zhang, J. Chen, Z. Hao, L. Jiao, Q. Ge, W.-F. Fu, X.-J. Lv, Highly efficient electrochemical hydrogenation of acetonitrile to ethylamine for primary amine synthesis and promising hydrogen storage. Chem Catal., 1-14 (2021).

20. M. E. Scofield, Y. Zhou, S. Yue, L. Wang, D. Su, X. Tong, M. B. Vukmirovic, R. R. Adzic, S. S. Wong, Role of chemical composition in the enhanced catalytic activity of Ptbased alloyed ultrathin nanowires for the hydrogen oxidation reaction under alkaline conditions. ACS Catal. 6, 3895-3908 (2016).

21. J. Huot, G. Liang, S. Boily, A. Van Neste, R. Schulz, Structural study and hydrogen sorption kinetics of ball-milled magnesium hydride. J. Alloys Compd. 293, 495-500 (1999).

22. L. Wang, A. Rawal, K.-F. Aguey-Zinsou, Hydrogen storage properties of nanoconfined aluminium hydride $\left(\mathrm{AlH}_{3}\right)$. Chem. Eng. Sci. 194, 64-70 (2019).

23. J. Graetz, B. C. Hauback, Recent developments in aluminum-based hydrides for hydrogen storage. MRS Bull. 38, 473-479 (2013).

24. Y. Chen, C.-Z. Wu, P. Wang, H.-M. Cheng, Structure and hydrogen storage property of ball-milled $\mathrm{LiNH}_{2} / \mathrm{MgH}_{2}$ mixture. Int. J. Hydrogen Energy. 31, 1236-1240 (2006).

25. Z. Xiong, G. Wu, J. Hu, P. Chen, Ternary imides for hydrogen storage. Adv. Mater. 16, $1522-1525$ (2004).

26. S. Liu, J. Liu, X. Liu, J. Shang, L. Xu, R. Yu, J. Shui, Hydrogen storage in incompletely etched multilayer $\mathrm{Ti}_{2} \mathrm{CTx}$ at room temperature. Nat. Nanotechnol. 16, 331-336 (2021).

\section{Acknowledgments:}

Funding:

The University of Akron, US

\section{Author contributions:}

D. Z. $\mathrm{Wu}^{\dagger}$ and J. L. $\mathrm{Li}^{\dagger}$ contributed equally to this work. D. Z. Wu designed and performed the half-cell experiments, analyzed the data and prepared the manuscript. J. L. Li conducted the full cell assembling, calibration and testing, and characterization of the reaction products. L. B. Yao and R. X. Xie contributed to full cell assembling and testing and results discussion. Z. M. Peng conceived the project, designed the experiments, and edited the manuscript.

\section{Competing interests:}

Authors declare that they have no competing interests.

\section{Data and materials availability:}

All data are available in the main text or the supplementary materials.

\section{Supplementary Materials}

Materials and Methods

Fig.S1 S13. Electrochemical measurements under half-cell conditions. 
Fig. S14. Photos of the assembled electrochemical full cell.

Fig. S15, 17, 20 22. Electrochemical measurements under half-cell conditions.

Fig. S16 NMR characterization results.

Fig. S18 19. MS characterization and data calibration.

(a)

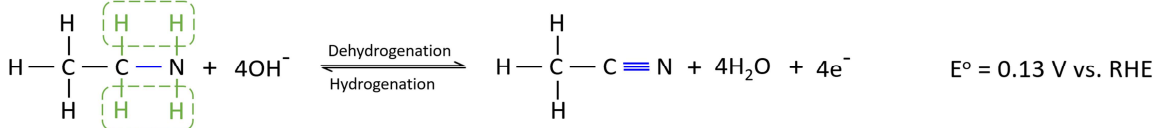

$$
\begin{aligned}
& 4 \mathrm{H}_{2} \mathrm{O}+4 \mathrm{e}^{-} \stackrel{\mathrm{HER}}{\stackrel{\mathrm{HOR}}{H}} 4 \mathrm{OH}^{-}+2 \mathrm{H}_{2}
\end{aligned}
$$

(b)

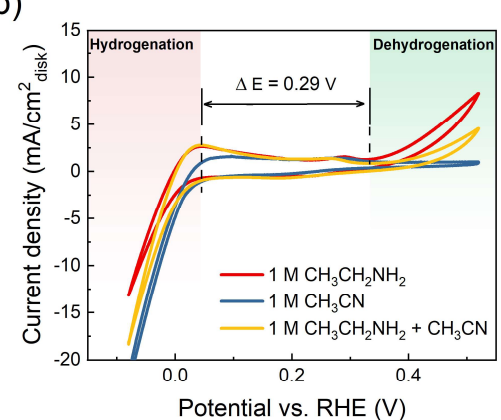

(e)

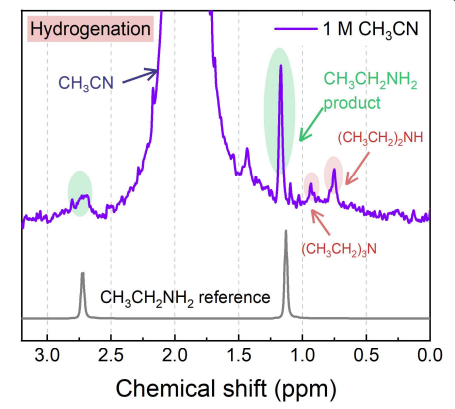

(c)

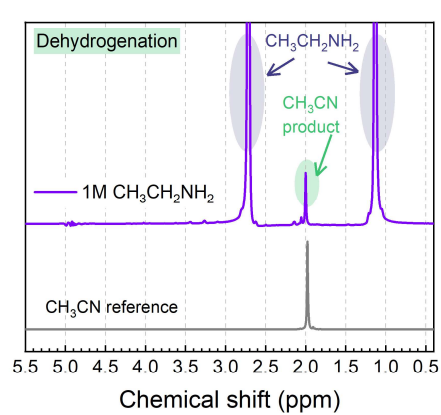

(f)

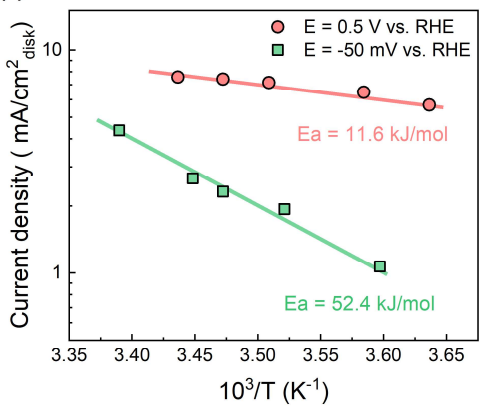

(d)

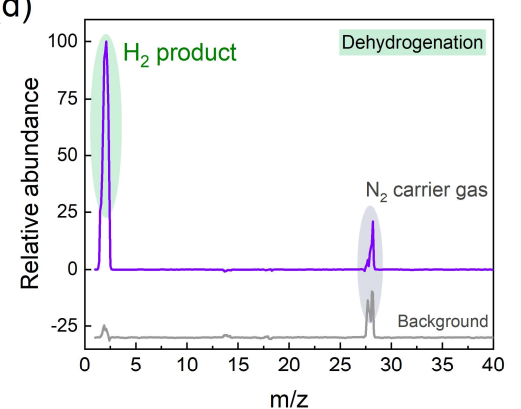

(g)

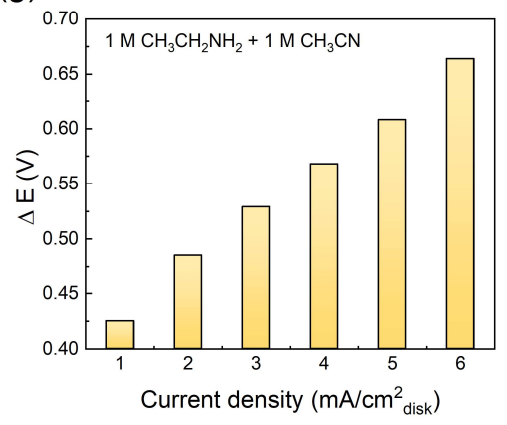

Fig. 1. Experimental measurements of electrochemical $\mathrm{CH}_{3} \mathrm{CH}_{2} \mathrm{NH}_{2} / \mathrm{CH}_{3} \mathrm{CN}$ redox properties in alkaline aqueous electrolyte under half-cell condition. (a) Equation and standard potential for electrochemical $\mathrm{CH}_{3} \mathrm{CH}_{2} \mathrm{NH}_{2} / \mathrm{CH}_{3} \mathrm{CN}$ redox reactions and hydrogen evolution and oxidation reactions under alkaline aqueous condition; (b) Cyclic voltammetry of commercial Pt black catalyst-loaded working electrode in $1 \mathrm{M} \mathrm{NaOH}$ aqueous solution with the addition of $1 \mathrm{M} \mathrm{CH}_{3} \mathrm{CH}_{2} \mathrm{NH}_{2}, 1 \mathrm{M} \mathrm{CH}_{3} \mathrm{CN}$, and $1 \mathrm{M} \mathrm{CH}_{3} \mathrm{CH}_{2} \mathrm{NH}_{2}+1 \mathrm{M} \mathrm{CH}_{3} \mathrm{CN}$, respectively; (c) ${ }^{1} \mathrm{H}$ NMR spectrum of liquid product from $\mathrm{CH}_{3} \mathrm{CH}_{2} \mathrm{NH}_{2}$ dehydrogenation obtained by applying $0.7 \mathrm{~V}$ vs. RHE for 10 hours, with $\mathrm{CH}_{3} \mathrm{CN}$ as a reference and (d) mass spectrum of gas product from the counter electrode in $\mathrm{CH}_{3} \mathrm{CH}_{2} \mathrm{NH}_{2}$ dehydrogenation experiment; (e) ${ }^{1} \mathrm{H} \mathrm{NMR}$ spectrum of liquid product from $\mathrm{CH}_{3} \mathrm{CN}$ hydrogenation obtained by applying $-0.4 \mathrm{~V}$ vs. RHE for 10 hours, with $\mathrm{CH}_{3} \mathrm{CH}_{2} \mathrm{NH}_{2}$ as a reference; (f) Arrhenius plots obtained at $0.5 \mathrm{~V}$ vs. RHE in $\mathrm{CH}_{3} \mathrm{CH}_{2} \mathrm{NH}_{2}$ dehydrogenation experiments and at $-50 \mathrm{mV}$ vs. $\mathrm{RHE}$ in $\mathrm{CH}_{3} \mathrm{CN}$ hydrogenation experiments; (g) Potential difference between $\mathrm{CH}_{3} \mathrm{CH}_{2} \mathrm{NH}_{2}$ dehydrogenation reaction and 
$\mathrm{CH}_{3} \mathrm{CN}$ hydrogenation reaction as a function of current density in $1 \mathrm{M} \mathrm{NaOH}$ aqueous solution with the addition of $1 \mathrm{M} \mathrm{CH}_{3} \mathrm{CH}_{2} \mathrm{NH}_{2}$ and $1 \mathrm{M} \mathrm{CH}_{3} \mathrm{CN}$.

(a)

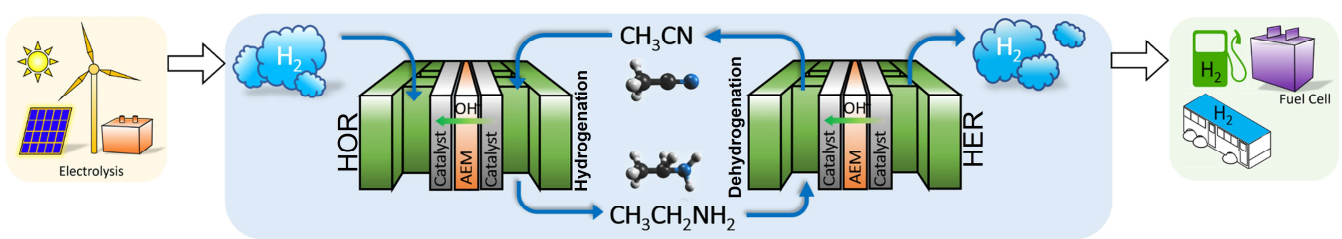

(b) $\quad \mathrm{CH}_{3} \mathrm{CN}$ hydrogenation for $\mathrm{H}_{2}$ uptake

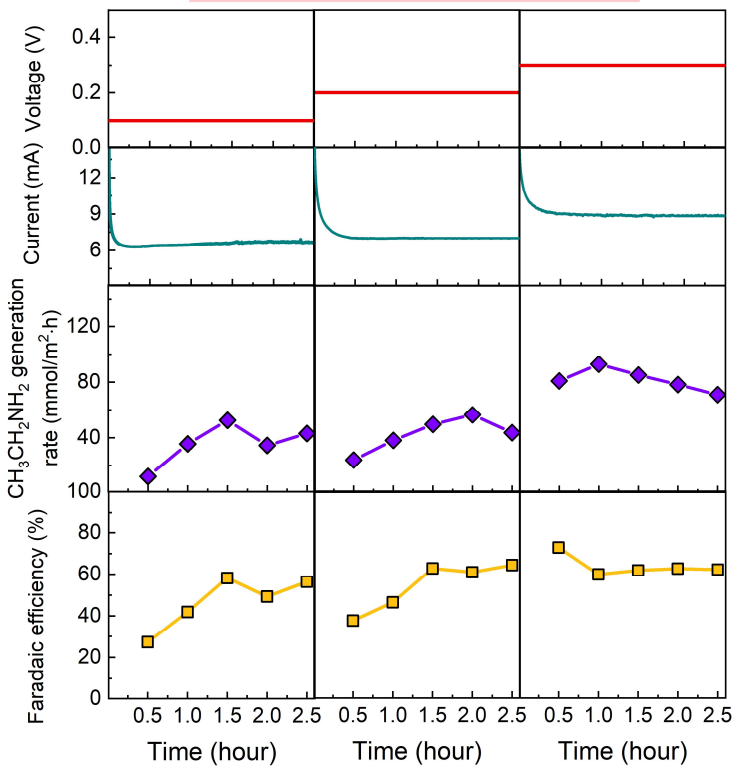

(c) $\quad \mathrm{CH}_{3} \mathrm{CH}_{2} \mathrm{NH}_{2}$ deydrogenation for $\mathrm{H}_{2}$ release
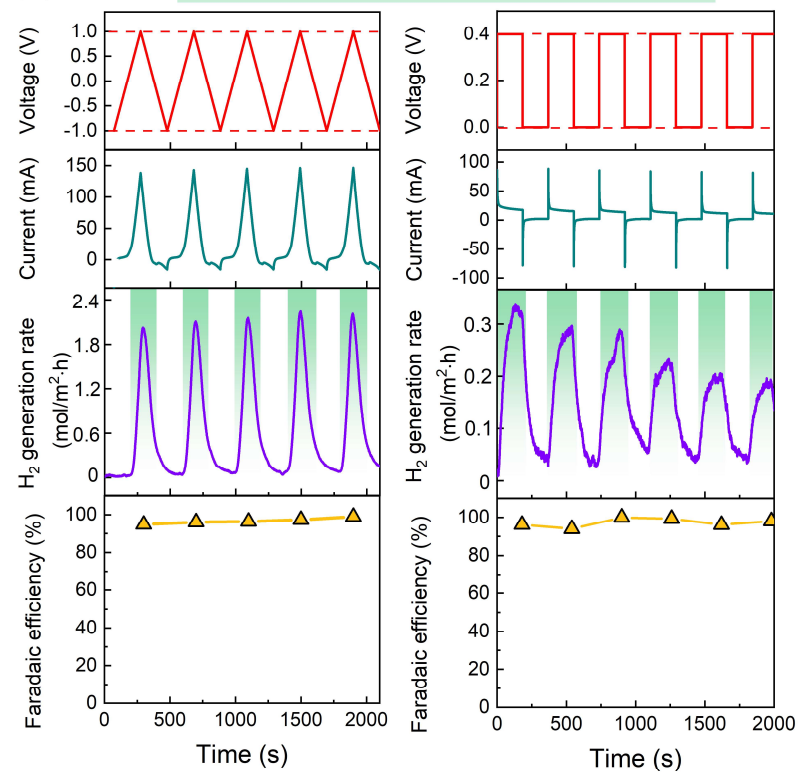

Fig. 2. Hydrogen uptake and release experiments using the electrochemical

$\mathrm{CH}_{3} \mathrm{CH}_{2} \mathrm{NH}_{2} / \mathrm{CH}_{3} \mathrm{CN}$ redox method in a full-cell system. (a) Schematic drawing of a full-cell system that realizes a complete cycle of hydrogen storage under ambient conditions by coupling the electrochemical $\mathrm{CH}_{3} \mathrm{CH}_{2} \mathrm{NH}_{2} / \mathrm{CH}_{3} \mathrm{CN}$ redox method with $\mathrm{HER} / \mathrm{HOR}$, with hydrogen production from renewable energy and hydrogen applications included to illustrate the sustainable hydrogen economy; (b) Chronoamperometry of $\mathrm{CH}_{3} \mathrm{CN}$ hydrogenation for $\mathrm{H}_{2}$ uptake at different cell voltage, and the measured $\mathrm{CH}_{3} \mathrm{CH}_{2} \mathrm{NH}_{2}$ generation rate and faradaic efficiency; (c) Cyclic voltammetry and on-and-off chronoamperometry of $\mathrm{CH}_{3} \mathrm{CH}_{2} \mathrm{NH}_{2}$ dehydrogenation for 
$\mathrm{H}_{2}$ release, and the measured $\mathrm{H}_{2}$ generation rate and faradaic efficiency under the testing conditions.

(a)

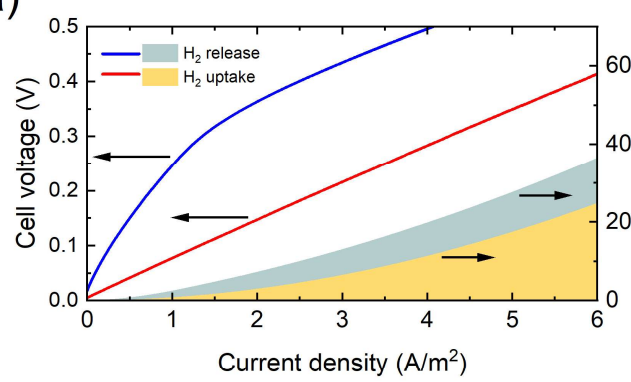

(c)

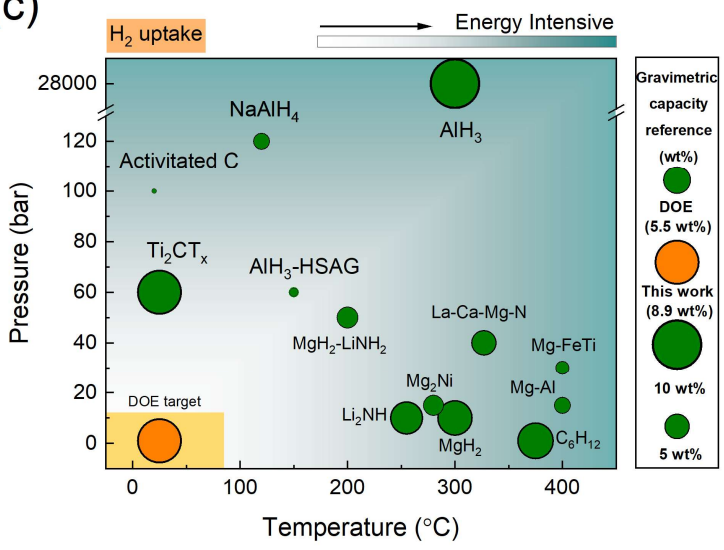

(b)
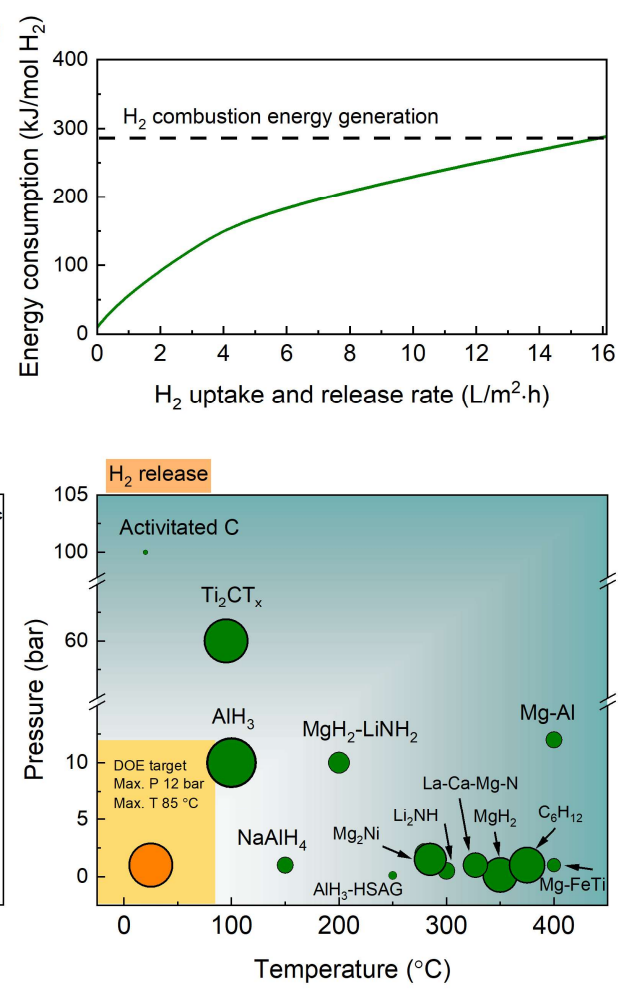

Fig. 3. Energy consumption analysis of the electrochemical $\mathrm{CH}_{3} \mathrm{CH}_{2} \mathrm{NH}_{2} / \mathrm{CH}_{3} \mathrm{CN}$ redox method for hydrogen storage and its technical advantages compared with literature studies. (a) Full-cell I-V curves for $\mathrm{H}_{2}$ uptake and release steps, and corresponding power consumption; (b) Calculated energy consumption for completing a complete hydrogen storage cycle as a function of $\mathrm{H}_{2}$ uptake and release rate; (c) Comparison of the electrochemical $\mathrm{CH}_{3} \mathrm{CH}_{2} \mathrm{NH}_{2} / \mathrm{CH}_{3} \mathrm{CN}$ redox method with literature data of other reported methods in terms of hydrogen storage capacity, operation pressure and temperature. 